\title{
A study on examining interrelationships among customer satisfaction, loyalty, and switching intent in industrial food suppliers
}

\author{
Hamid Reza Saeedniya ${ }^{a}$ and Somaye Abedini ${ }^{b^{*}}$
}

\begin{abstract}
${ }^{a}$ Assist. Prof. \& Faculty Member, Department of Commercial Management, School of Management, Tehran North Branch, Islamic Azad University (IAU), Tehran, Iran

${ }^{b}$ M.Sc. Student, Department of Commercial Management, School of Management, Tehran North Branch, Islamic Azad University (IAU), Tehran, Iran

C H R O N I C L E

Article history:

Received January 2, 2014

Accepted 8 May 2014

Available online

June 12014

Keywords:

Customer satisfaction

Brand loyalty

Switching intend

Variety seeking

Involvement
\end{abstract}

\section{Introduction}

Brand loyalty is one of the most important concepts in brand literature (Bloch et al., 1993; Aaker, 2004). Customer's loyalty toward brand can increase firm's share price (Gregory \& Wiechmann, 1997). In addition, firms' market share maintains close relationship with net profit and capital used return (Arora \& Stoner, 1996; Bharadwaj et al., 1993). Company efforts to motivate customers to switch from competitive brands to their own or to induce them to repurchase their own brands are very important in their marketing activities (Ambler et al., 2002). Therefore, investigating customer variety-seeking orientation and level of involvement in decision-making plays essential role in explaining customers' product selection activities (Auh \& Johnson, 2005; Alloza, 2008). There are literally various associated with brand loyalty.

\footnotetext{
*Corresponding author. Tel: +98-912-7948500

E-mail addresses: saz 1363@yahoo.com (S. Abedini)

C 2014 Growing Science Ltd. All rights reserved. doi: $10.5267 /$ j.msl.2014.6.002
} 
Bigne and Blesa (2003), for instance, investigated market orientation, trust and satisfaction in dyadic relationships: a manufacturer-retailer analysis. According to Mandel and Nowlis (2008), consumers who make predictions about uncertain events enjoy observing those events substantially less than those who do not make any predictions, in spite of consumers' expectations to the contrary. Berry (2000) presented a service-branding model, which underscores the salient effect of customers' service experiences in brand formation. The author reported that branding was not just for tangible products; it was a principal success driver for service organizations. Bitner (1992) presented a typology of service organizations and gave a conceptual framework for exploring the effect of physical surroundings on the behaviors of both customers and employees. Bitner (1990) performed an investigation on evaluating service encounters by looking in the effects of physical surroundings and employee responses. Chaudhry and Walsh (1996) performed an assessment of the effect of counterfeiting in international markets.

\section{The proposed study}

This study intends to examine interrelationships among customer satisfaction, loyalty, and switching intent in industrial food suppliers and verifies the moderating effect of customer variety-seeking orientation and purchase decision involvement. The population of this study includes all customers who purchase foods from industrial food services in city of Tehran, Iran. The sample size is calculated as follows,

$$
N=Z_{\alpha / 2}^{2} \frac{p \times q}{e^{2}},
$$

where $N$ is the sample size, $p=1-q$ represents the probability, $z_{\alpha / 2}$ is CDF of normal distribution and finally $\varepsilon$ is the error term. For our study we assume $p=0.5, z_{\alpha / 2}=1.96$ and $e=0.05$, the number of sample size is calculated as $N=384$. The study uses a questionnaire consists of 20 questions and Fig. 1 shows details of the proposed study,

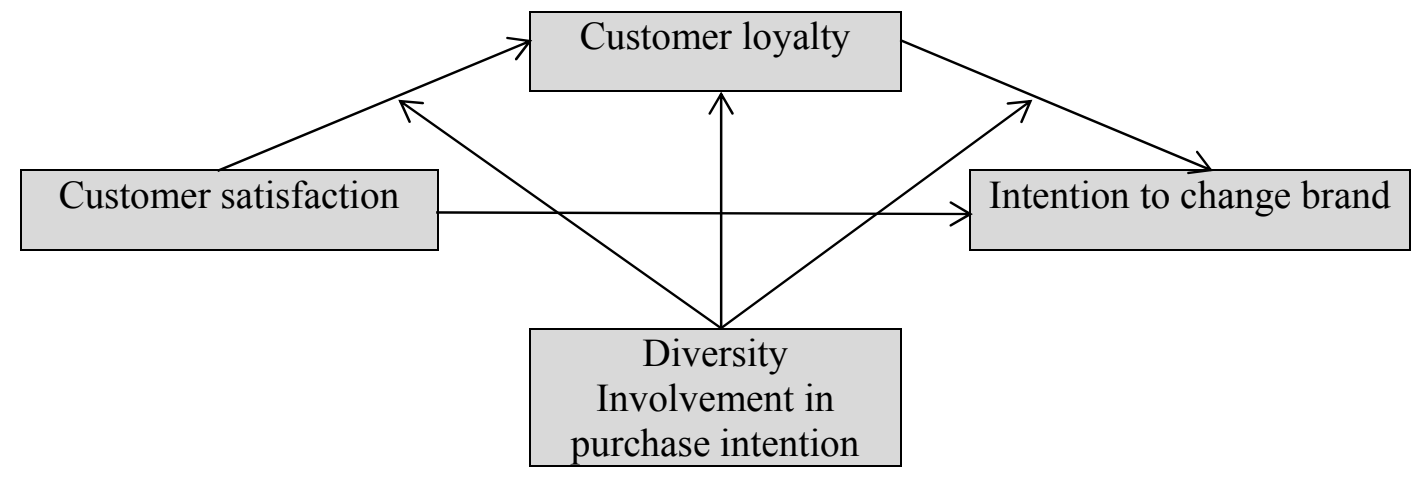

Fig. 1. The proposed study

Based on the framework of Fig. 1 the following five hypotheses are considered.

1. Customer satisfaction influences positively on customer loyalty (Chaudhuri, 1999).

2. Customer satisfaction negatively influences on customer's intention to change brand.

3. Customer loyalty negatively influences on customer's intention to change brand.

4. Customer's interest in diversity mediates the relationship among customer satisfaction, loyalty and customer intention on change brand. 
5. Customer's involvement mediates the relationship among customer satisfaction, loyalty and customer intention on change brand.

The study uses structural equation modeling to examine the hypotheses of the survey and the implementation is executed on LISREL software package. Cronbach alpha for customer satisfaction, loyalty, change intention, diversity and involvement are calculated as $0.86,0.89,0.90,0.86$ and 0.89 , respectively. Table 1 shows details of some statistical observations.

\section{Table 1}

The summary of some statistical observations

\begin{tabular}{lcc}
\hline Criterion & The results & Desirable value \\
\hline Chi-Square/df & 2.3 & $<3.0$ \\
Goodness of fit index (GFI) & 0.94 & $>0.90$ \\
Root Mean Square Estimated (RMSEA) & 0.001 & $<0.1$ \\
Certified Factor Index (CFI) & 0.92 & $>0.90$ \\
Normalized Factor index (NFI) & 0.97 & $>0.90$ \\
NNFI & 0.95 & $>0.90$ \\
\hline
\end{tabular}

As we can observe from the results of Table 1, all statistical observations were well above the acceptable limit and we therefore may examine the hypotheses based on the results of SEM implementation.

\section{The results}

In this section, we present details of our findings on testing various hypotheses based on SEM implementation shown in Fig. 2 as follows,

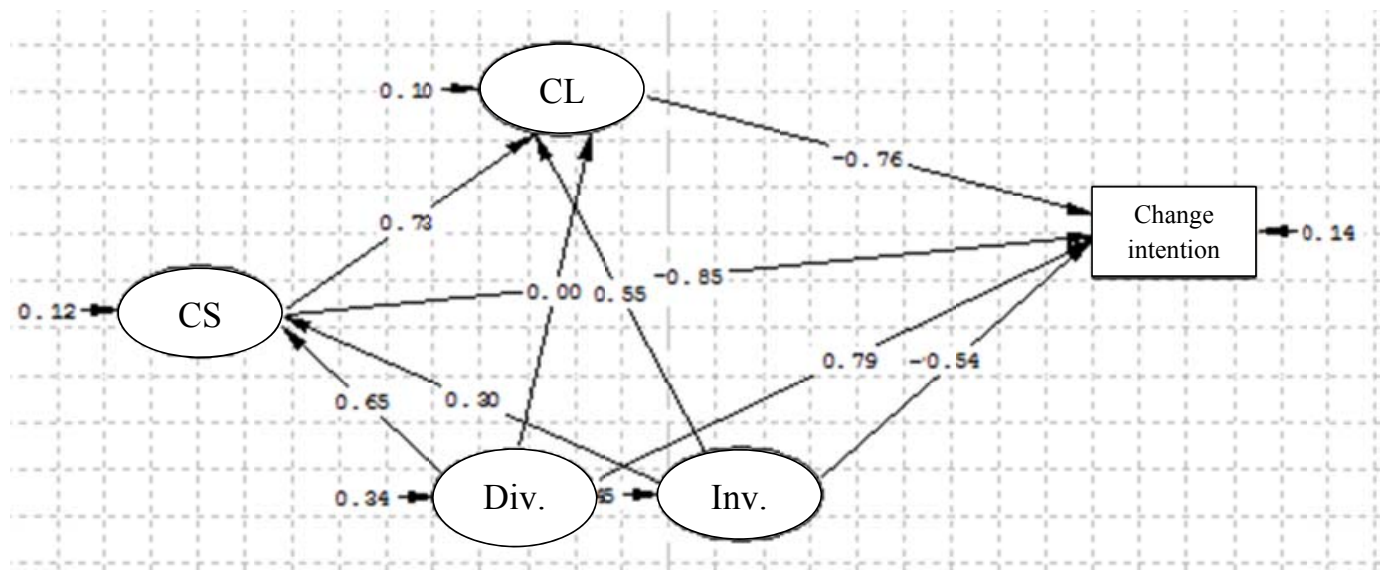

CS: Customer satisfaction, CL: Customer loyalty, Div.: Customer intention for diversity, Inv.: Customer involvement

Fig. 2. The results of standard coefficients

Table 2 summarizes the results of our findings, which confirms all hypotheses of the survey.

\section{Table 2}

The summary of standard coefficients

\begin{tabular}{ccccc}
\hline Hypothesis & $\beta$ & t-value & Sig. & Result \\
\hline First & 0.73 & 3.97 & 0.000 & Confirmed \\
Second & -0.81 & 4.91 & 0.000 & Confirmed \\
Third & -0.72 & 3.3 & 0.000 & Confirmed \\
Fourth & 0.79 & 2.17 & 0.000 & Confirmed \\
Fifth & -0.54 & 2.97 & 0.000 & Confirmed \\
\hline
\end{tabular}




\section{Conclusion}

In this paper, we have presented an empirical investigation to examine interrelationships among customer satisfaction, loyalty, and switching intent in industrial food suppliers. The results of our survey have confirmed that customer satisfaction influences positively on customer loyalty $(\beta=0.73$, t-value $=3.97)$, customer satisfaction negatively influences on customer's intention to change brand ( $\beta=-0.81$, t-value $=4.91)$, customer loyalty negatively influences on customer's intention to change brand $(\beta=-0.72$, t-value $=3.3)$. In addition, in our survey, customer's interest in diversity mediates the relationship among customer satisfaction, loyalty and customer intention on change brand $(\beta=$ 0.79 , t-value $=2.17$ ) and finally, customer's involvement mediates the relationship among customer satisfaction, loyalty and customer intention on change brand $(\beta=-0.54$, t-value $=2.97)$.

\section{Acknowledgement}

The authors would like to thank the anonymous referees for constructive comments on earlier version of this paper.

\section{References}

Aaker, D. A. (2004). Leveraging the corporate brand. California management review, 46(3), 6-18.

Alloza, A. (2008). Brand engagement and brand experience at BBVA, the transformation of a 150 years old company. Corporate Reputation Review, 11(4), 371-379.

Ambler, T., Bhattacharya, C. B., Edell, J., Keller, K. L., Lemon, K. N., \& Mittal, V. (2002). Relating brand and customer perspectives on marketing management. Journal of Service Research, 5(1), $13-25$.

Arora, R., \& Stoner, C. (1996). The effect of perceived service quality and name familiarity on the service selection decision. Journal of Services Marketing,10(1), 22-34.

Auh, S., \& Johnson, M. D. (2005). Compatibility effects in evaluations of satisfaction and loyalty. Journal of Economic psychology, 26(1), 35-57.

Berry, L. L. (2000). Cultivating service brand equity. Journal of the Academy of Marketing Science, 28(1), 128-137.

Bharadwaj, S. G., Varadarajan, P. R., \& Fahy, J. (1993). Sustainable competitive advantage in service industries: A conceptual model and research. Journal of marketing, 57(4), 83.

Bigne, E., \& Blesa, A. (2003). Market orientation, trust and satisfaction in dyadic relationships: a manufacturer-retailer analysis. International Journal of Retail \& Distribution Management, 31(11), 574-590.

Bloch, P. H., Bush, R. F., \& Campbell, L. (1993). Consumer "accomplices" in product counterfeiting: a demand side investigation. Journal of Consumer Marketing, 10(4), 27-36.

Bitner, M. J. (1990). Evaluating service encounters: the effects of physical surroundings and employee responses. The Journal of Marketing, 54(2), 69-82.

Bitner, M. J. (1992). Servicescapes: The impact of physical surroundings on customers and employees. Journal of marketing, 56(2), 57-71.

Chaudhuri, A. (1999). Does brand loyalty mediate brand equity outcomes?. Journal of Marketing Theory and Practice, 136-146.

Chaudhry, P. E., \& Walsh, M. G. (1996). An assessment of the impact of counterfeiting in international markets: the piracy paradox persists. The Columbia Journal of World Business, 31(3), 34-48.

Gregory, J. R., \& Wiechmann, J. G. (1997). Leveraging the corporate brand. Lincolnwood, IL: NTC Business Books.

Mandel, N., \& Nowlis, S. M. (2008). The effect of making a prediction about the outcome of a consumption experience on the enjoyment of that experience. Journal of Consumer Research, 35(1), 9-20. 